\title{
Non-Carbohydrate Components on the Surface of Starch Granules According to the Hardness of Wheat
}

\author{
Izabella Kwaśniewska-Karolak ${ }^{1}$, Justyna Rosicka-Kaczmarek ${ }^{1}$, Ewa Nebesny ${ }^{1}$, \\ Maria Stasiuk $^{2}$ \\ ${ }^{1}$ Institute of Chemical Technology of Food, Technical University of Lodz, Lodz, Poland \\ ${ }^{2}$ Laboratory of Lipids and Liposomes, Faculty of Biotechnology, University of Wroclaw, Wroclaw, Poland \\ Email: ${ }^{\text {izabella.kwasniewska-karolak@p.lodz.pl }}$
}

Received 28 December 2014; accepted 9 January 2015; published 13 January 2015

Copyright (C) 2015 by authors and Scientific Research Publishing Inc.

This work is licensed under the Creative Commons Attribution International License (CC BY).

http://creativecommons.org/licenses/by/4.0/

(c) O) Open Access

\section{Abstract}

An attempt was made to demonstrate the usefulness of pre-knowledge of the quality and quantity analysis of non-carbohydrate components of starch surface, such as proteins and lipids, in starch isolated from wheat with varying degrees of hardness, for receiving glucose hydrolysates. The chemical composition of starches isolated from wheat grains of different hardness was examined. The amount of protein fraction (surface proteins, puroindolins and internal proteins), total and surface lipids, apparent amylose, phosphorous and pentosans contents were evaluated. It was found that starches, depending on the hardness of wheat grain, have a different chemical composition. A clear influence of wheat hardness on lipid and proteins content on the surface of starch grains and on apparent amylose was proved. It was showed that the presence of polar lipids (glycoand phospholipids) on the surface of starch was connected with their role in binding of surface proteins fraction (friabilins) to starch grains. There was a clear positive correlation between the amount of lipid fraction on starch surface and the amount of protein fraction, depending on wheat hardness. Starches from soft wheat varieties were characterized by higher amounts of proteins and lipids on their surface. In addition, it was determined that basing on the knowledge of mechanical properties of wheat grains, namely its hardness and initial starch chemical content analysis, one may predict its further directions of processing, including evaluation, whether the starch from a given wheat variety would be appropriate for obtaining hydrolysates with good physicochemical properties.

\section{Keywords}

Hardness of Wheat, Wheat Starch Surface, Puroindolines, Lipids, Glucose Hydrolysates

\footnotetext{
${ }^{*}$ Corresponding author.
}

How to cite this paper: Kwaśniewska-Karolak, I., Rosicka-Kaczmarek, J., Nebesny, E. and Stasiuk, M. (2015) Non-Carbohydrate Components on the Surface of Starch Granules According to the Hardness of Wheat. Food and Nutrition Sciences, 6, 112-123. http://dx.doi.org/10.4236/fns.2015.61012 


\section{Introduction}

Starch, the main plant storage polysaccharide, depending on its botanical origin, is accompanied by small amounts of compounds such as proteins, lipids and phosphorus.

Lipids are a major non-starch component of cereal starches [1] [2]. Depending on their location in the grain, they can be classified into one of three classes: non-starch, surface and interior lipids. Non-starch lipids which consist of triglycerides, diacylglycolipids and phospholipids, form in the membrane and endospores' spherosomes and loosely link to the starch grains [3]. The most important group of wheat starch lipids is lysophospholipids, among which lysophosphatidylcholine (LPC) determines the greatest part. The amount of it may be up to $70 \%$ - 90\% of total lipids. During isolation of starch grains swelling may occur, resulting in absorption of free fatty acids and monoacyl lipids into the internal layers of grains. Hence, non-starch lipids are described as external lipids of starch [3] [4].

Triglycerides, free fatty acids, glycolipids and phospholipids belong to the fraction of starch surface lipids. They contain a greater amount of monoacyl lipids, compared with non-starch lipids, which simplify the formation of amylose-lipid complexes on the surface of starch grains [5].

Internal starch lipids are located inside the intact cereal grains of starch. These are mainly monoacyl lipids, namely free fatty acids and lysophospholipids, which may exist as complexes with amylose in native starch [6].

In the process of milling grain, due to starch grain damage, part of proteins, which are in its interior are adsorbed on the surface of the starch. These proteins bear a common name of surface proteins [7].

There are two basic types among the proteins associated with starch: storage proteins (gluten, gliadin) and SGAP proteins (starch-granule-associated proteins), which differ from the storage proteins and are closely associated with the surface of starch grains and form its integral part. These proteins are a different type of polypeptides than the storage proteins. By means of gel electrophoresis (SDS-PAGE) 10 major polypeptide chains are separated which molecular masses in the range from 5 to $149 \mathrm{kDa}$. Considering the molecular mass, these proteins can be divided into 2 groups: one group of surface proteins with masses $\sim 5,8,15,19$ and $30 \mathrm{kDa}$ and the other group of interior proteins with high-molecular weight $\sim 60,77,86,95$ and $149 \mathrm{kDa}$. In addition to the above, there are two types of proteins with a molecular mass of 100 and $105 \mathrm{kDa}$, which are unique to the species Triticum [7].

This group of proteins in mass close to $15 \mathrm{kDa}$ is called friabilins, (from the English word "friable") [13], which is associated with their presence on the surface of starch grains of soft wheat varieties. Much less friabilins are found on the surface of starch grains of hard wheat, whereas their presence isn't found on the surface of starch from durum wheat. These proteins are also referred to as a specific marker for grain softness. The group of these proteins belongs puroindoline a and b and GSP-1 (grain softness protein) [8]. Among the proteins present on the surface of the starch the specific proteins involved in lipid binding are also distinguished. These two proteins are mainly non-specific lipid transfer protein (nsLTPs) and puroindoline [9]. Binding puroindolines with lipids on the surface of starch granules is related to the adhesion between starch granules and protein matrix, which also affects the properties of wheat endosperm [10]. Two types of interactions between puroindolines and lipid membrane were found-hydrophobic interactions between residues of tryptophan and the end of the lipid and the electrostatic interaction between residues of arginine/lysine in tryptophan rich domain and the main phosphate groups of lipids [10] [11].

It is believed that the polar lipids present on the surface of the starch are involved in interactions between proteins and starch [11] [12].

According to Oda and Schofield [14], participation of lipids in binding of proteins may be indirect (lipids act as a bridge between starch and protein) or direct (lipids may cause conformational changes of proteins, allowing them to be associated with starch). Negatively charged lipid increases the strength of interactions between puroindoline and lipids, and secondary structure of puroind oline doesn't change due to the interaction with lipids [15]. Determinants of binding and affinity of lipids to proteins are length of lipid alkyl chain, electrostatic charge and participation of hydrogen bonds. According to this model, a gradual increase of hydrophobicity within the tryptophan domain, causes a binding of a growing number of lipids. Research of Kooijmani et al., [15], confirmed the participation of tryptophan domain in the binding of lipids in which the most important role was played by the domain structure.

The hardness of wheat has a significant impact on the quantity and qualitative composition of polar lipids present on the surface of starch [4]. Polar lipids studied by Greenblatt, Bettge and Morris [11] have been bound 
mainly on the surface of starch grains of soft wheat varieties, but they were not on the surface of starch from hard wheat varieties. However, these lipids were present in much larger quantities (more than 10 -fold) in the intact grains of wheat, both soft and hard. Morrison, Law, Wylie and Coventry [15] and Morrison and Laignelet [16] showed that the presence of free lipids in the endosperm of wheat was also correlated with the hardness of its grain (an increase of free lipids was associated with a decrease in hardness). Noteworthy is the phenomenon of repetition of the same pattern in the case of friabilins and polar lipids that are present in the starches isolated from soft wheat, while in the hard wheat starches only small quantities were found. Polar lipids beside friabilins may thus become a specific marker of soft grain.

The hardness of wheat grain determines conditions of grain milling and directions of processing of flour and starch. Knowledge of the factors determining the characteristics of isolated starch can help in choosing appropriate processing conditions and directions of use of obtained material, so the product obtained after starch hydrolysis will have better properties.

Starches from soft wheat are characterized by a lower degree of damage, in contrast to starch from hard wheat grains, which makes them more susceptible to enzymatic hydrolysis.

Previous research [17] indicated that quality and quantity of lipid compounds in starch had a significant influence on the physicochemical properties of derived glucose hydrolysates depending on the variety of wheat. High amounts of starch lipids negatively influenced filtration properties, the degree of saccharification, color and transparency of obtained hydrolysates. The presence of lipids in starch affected its susceptibility to amylolytic enzymes, closely related to the quality of hydrolysates.

Based on the initial characterization even only qualitative and quantitative composition of the lipid fraction of starch can be pre-predict if the starch obtained from the wheat grain of a certain hardness is suitable for the preparation of the glucose hydrolysates.

The aim of this study was, therefore, the attempt to determine the suitability of these starches to obtain glucose hydrolysates, on the basis of preliminary analysis of the quality and quantity of starch surface lipids in dependence of hardness of wheat. The analysis would enable to predict the physicochemical properties of hydrolysates and the process of hydrolysis itself. Both, the process and chemical composition of starch, determine susceptibility of starch grains to the amylolytic enzymes, which reflects the glucose hydrolysate filtration speed, degree of saccarification, color and transparency.

\section{Materials and Methods}

\subsection{Raw Materials}

Raw materials used for the study were starches isolated from four wheat varieties with different degrees of hardness, collected in 2006. Wheat varieties STH, Tonacja and Sukces from the Department of Plant Breeding Strzelce and wheat variety Bombona from Danko Plant Breeding Institute in Poland were used.

Grains of wheat, from which the analyzed starches were obtained, were tested for hardness, using for this purpose the Single-Kernel Characterization System 4100 (Perten Instruments) SKCS method. Hardness measurement was made on 300 individual grains in triplicate. After milling the grain, starches were isolated from flours by applying Martin's technology [18] (starch washing with tap water from a thick dough in a weight ratio of flour to water 2:1).

Starches were characterized by dry matter content [19], total protein using Kjeldahl method [20], total surface protein and puroindoline fractions and internal protein [21]. In order to determine the fraction of total surface protein in the starch the samples were subject to extraction using $2 \%$ solution of SDS for 30 minutes, at room temperature $\left(10 \mathrm{~cm}^{3} 2 \%\right.$ SDS in water for $1 \mathrm{~g}$ of starch). Starch was recovered by centrifugation of suspensions at a speed $3600 \mathrm{rpm}$ within $5 \mathrm{~min}$. The supernatant was discarded, starch was washed twice with water and dried in air. Thus obtained starch was used to determine the amount of protein remaining after extraction. Total protein on the surface was calculated from the difference of total protein in starch and after extraction with $2 \%$ water solution of SDS.

The fraction of puroindoline type proteins on the surface of starch was determined by earlier subjecting starch to extraction using a selective solvent for this group of proteins, i.e. a mixture of $50 \%$ water solution of isopropanol and $0.05 \mathrm{~N} \mathrm{NaCl}$ in 1:1 ratio $\left(10 \mathrm{~cm}^{3}\right.$ mixture per $1 \mathrm{~g}$ starch) at $45^{\circ} \mathrm{C}$ during 1 hour [21]. Starch was recovered by centrifugation and dried as described above; its protein content was analyzed by Kjeldahl method [20]. Based on these results, percentages of each protein fraction respect to total protein were calculated. 
Total lipids content and the internal lipids were determined by Soxhlet Weibull method with acid hydrolysis [19], after prior extraction of surface lipids from wheat starch by $65 \%$ aqueous propanol solution at room temperature (30 min, $1 \mathrm{~g}$ of wheat starch in $20 \mathrm{~cm}^{3}$ propanol, centrifuged at a speed of $3600 \mathrm{rpm}$ within 5 min, starches were washed twice with distilled water, centrifuged again and air dried at room temperature). The amount of lipids on the surface of starch granules was calculated from the difference between the total lipid content and the internal lipids of starch granules. Also phosphorus was determined using atomic absorption spectrophotometry method. Starches were mineralized with a mixture of concentrated acids: sulfuric and nitric (1:1) using $60 \mathrm{~cm}^{3} / 10 \mathrm{~g}$ of starch [22].

The total pentosan content was determined by colorimetric method [23] and the apparent amylose with DMSO [16].

\subsection{The Study of Co-Occurrence Protein and Lipids on the Surface of Wheat Starch Granules Depending on the Hardness of Wheat Grain}

For this purpose, indirect methods were used, i.e. by determining the qualitative composition of the lipid fraction of starch grains by thin layer chromatography method TLC and gel electrophoresis SDS-PAGE.

\subsubsection{Extraction of Lipids}

Free lipids (external), bound (surface) lipids, and internal lipids were isolated as was described earlier [11]. All obtain crude extracts were dried with nitrogen at room temperature and used for further analysis.

\subsubsection{Separation of Lipid Fractions}

Group separation of surface (bound) lipids was accomplished using procedures described earlier [11] using unmodified silica gel column Chromabond ${ }^{\circledR}$ (500 mg of silica gel with volume $3 \mathrm{ml}$, Macherey-Nagel, Düren, Germany) installed on SPE system 12G (Mallinckrodt Baker, Griesheim, Germany). All eluted lipids fractions were evaporated under $\mathrm{N}_{2}$ gas at room temperature and used for further analysis.

\subsubsection{Chromatographic Analysis of Lipids}

The crude extracts of a surface lipids as well as its fractions obtained in SPE method (neutral lipids, glycolipids and phospholipids) were redissolved in chloroform and methanol (1:1, by volume) to a final concentration of 60 mg starch equivalents per microliter and were chromatographed on precoated thin-layer silica gel G plates (20 × $20 \mathrm{~cm}$ ) (Macherey-Nagel, Düren, Germany). The plates were prewashed by vertical development for $19 \mathrm{~cm}$ with chloroform and methanol (1:1, by volume) to remove impurities and air dried at room temperature. The plates were spotted with $5 \mu \mathrm{l}$ of appropriate lipid solution per lane.

The neutral lipids and glycolipids were separated as was described earlier [11]. The phospholipids were separated in chloroform/methanol/acetic acid/distilled water (60:50:1:4, by volume) [24].

After development, the plates were air dried and the spots on the plates were visualized by iodide. To detect amino-lipids, the TLC plates was sprayed with $0.25 \%$ ninhydrine in acetone and then heated at $110^{\circ} \mathrm{C}$ [25]. Glycolipids were detected by spraying by $0.1 \%$ orcinol in $\mathrm{H}_{2} \mathrm{SO}_{4} /$ methanol (20:80, by volume) followed by heating at $120^{\circ} \mathrm{C}$ [26]. Sterols and sterol esters were detected by spraying with $0.05 \% \mathrm{FeCl}_{3} \times 6 \mathrm{H}_{2} \mathrm{O}$ solution in $5 \%$ acetic acid $/ 5 \% \mathrm{H}_{2} \mathrm{SO}_{4}$ and then heating at $100^{\circ} \mathrm{C}$ for $3 \mathrm{~min}$ [27].

\subsubsection{Determination of the Composition of the Fraction of Surface Proteins}

Determination of the qualitative composition of the fraction of surface proteins in the native starch was performed by gel electrophoresis SDS PAGE [28].

The study was based on confirmation of the presence of surface proteins, in particular friabilins (puroindolins) with a molecular weight of about $15 \mathrm{kDa}$, in the starch grains of different wheat varieties, depending on the hardness of grains [28]. Vertical electrophoresis was carried out using the omni PAGE Maxi Cleaver Scientific Ltd. apparatus, the surface of the gel $16 \mathrm{~cm} \times 17.5 \mathrm{~cm}$. Electrophoresis was carried out in denaturing conditions (SDS-PAGE) using polyacrylamide gels_-8\% loading gel and 12\% separating gel. Electrophorograms stained by silver method according to Gromowa and Celis, [29]. For the separation of surface proteins $8 \%$ loading gel and $12 \%$ separating gel were used. The samples in an amount of $30 \mu \mathrm{m}$ were applied into the gel wells. Starch weight taken for determination was $200 \mathrm{mg}$. Standard included proteins' marker with molecular weights: $66 \mathrm{kDa}$, 45 kDa, 36 kDa, 29 kDa, 24 kDa + 20 kDa and 15 kDa. 


\subsection{Statistical Analysis}

The results were evaluated statistically by using analysis of variance and significance test of differences F-Snedecor and T-Student at the significance level of 0.05, using the computer program Statistica 7.1.

\section{Results and Discussion}

Types of wheat, from which examined starches were isolated were characterized by degree of hardness. Based on this discriminant value, wheat grains were classified as soft or hard wheat (Table 1). STH variety is classified as soft (hardness 15), Tonacja, Bombona and Sukces are considered as hard varieties (hardness, 72, 73, 63 respectively). Table 1 contains a complete characterization of selected wheat varieties for testing. Three of them are winter varieties (STH, Tonacja, Sukces), and spring variety (Bombona). STH wheat variety is not yet entered into the register of varieties, the other three already are.

Tonacja and Sukces belong to the technological value group A, while Bombona to E.

The results of the analysis of chemical composition of starches derived from selected for testing wheat varieties with different degrees of hardness are given in Table 2.

Statistical analysis examined the chemical composition of starch indicates the presence of significant differ depending on the hardness of wheat from which starch is derived. Starch from soft wheat variety-STH significantly different from the rest in terms of the protein content, surface and internal lipids, starch, amylose, pentosans and phosphorus. This confirms the significant influence of wheat hardness on the chemical composition of isolated starch.

Starches derived from examined wheat cultivars have a dry weight in the range of $89.14 \%$ for Sukces to $90.17 \%$ d.m. for Tonacja. These differences may be related to the degree of starch damage. From the soft grains, starch granules are obtained with less damage, meaning it absorbs less water than the starch derived from hard grains, however the results do not confirm this dependency.

Table 1. Characteristics of wheat cultivars.

\begin{tabular}{ccccc}
\hline \multirow{2}{*}{ Feature } & \multicolumn{3}{c}{ Wheat variety } \\
\cline { 2 - 5 } & STH & TONACJA & $\begin{array}{c}\text { BOMBONA } \\
\text { Hard }\end{array}$ & $\begin{array}{c}\text { SUKCES } \\
\text { Hard }\end{array}$ \\
Vegetation period & Soft & Winter & Spring & Winter \\
Year of admission to the register & - & 2001 & 2005 & 2001 \\
Group of technological values & - & A & E & 73 \\
The hardness of wheat & 15 & 72 & 63 \\
\hline
\end{tabular}

Table 2. Content of selected chemical elements isolated from wheat starch with different degrees of hardness.

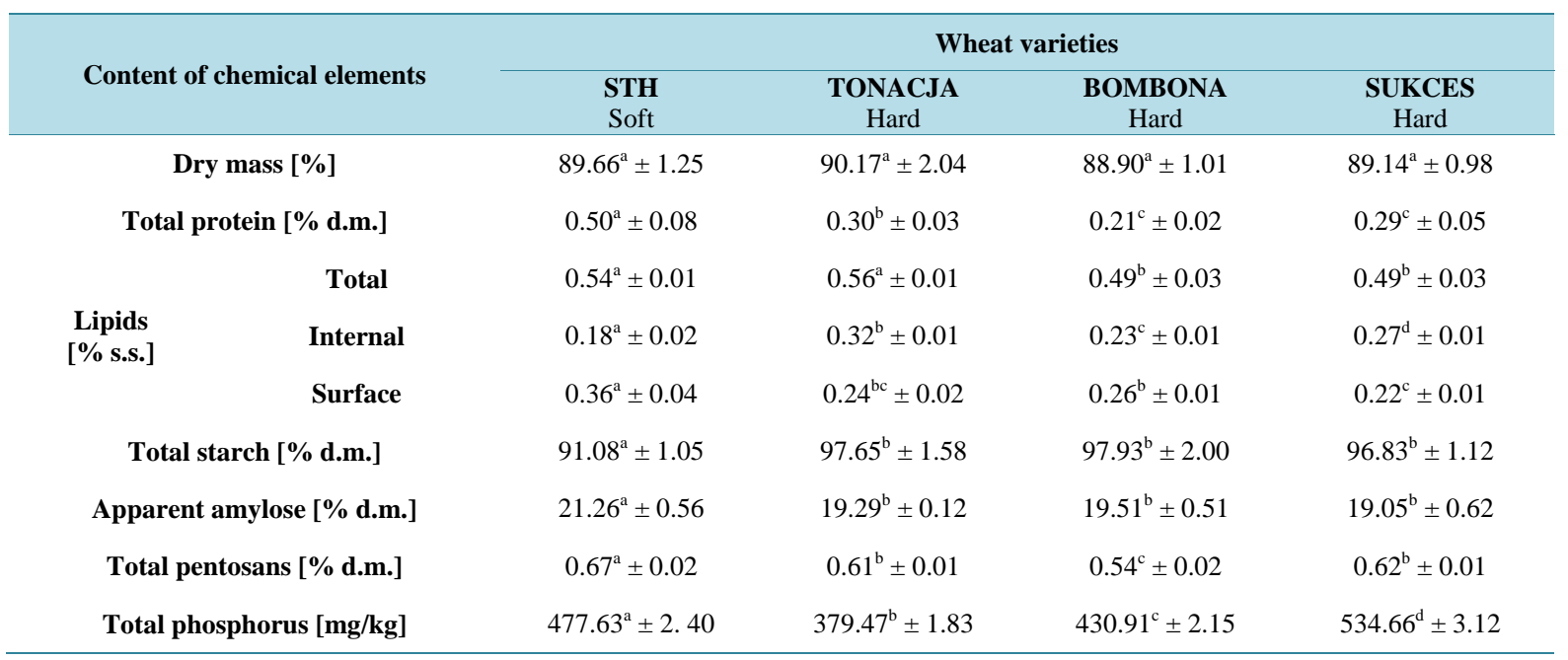


Research carried out by other authors [30] shows that lipids are a significant part of non-carbohydrate components of wheat starch, up to $1 \%$ by dry weight.

Depending on the variety and hardness of wheat from which starch came from, total lipid content ranged from 0.49\% d.m. for wheat varieties Sukces and Bombona to 0.56\% d.m. for Tonacja.

Starch from soft wheat (STH) contains more surface lipids $0.36 \%$ d.m. than starches from hard wheat (Tonacja, Bombona, Sukces): $0.24 \%$ d.m. for Tonacja variety, 0.26\% d.m. for Bombona and 0.22\% d.m. for Sukces. It can be concluded that the least lipids inside are in starch grains from STH soft variety.

These data show, that in the case of total lipid fraction there is no clear differentiation in the amount of total lipids in starches derived from wheat of different hardness. However, much greater differentiation between starches isolated from soft and hard wheat is visible in the fraction of lipids adsorbed on the surface of starch grains. Starches isolated from soft wheat varieties, i.e. STH contain higher amount of starch surface lipids. It can be seen, that knowledge of the quantity of total lipid fraction of starch does not fully reflect the impact of the hardness of wheat on the diversity of this factor. Only starch surface lipids content confirm the strong influence of wheat hardness on isolated starch composition.

The next carbohydrate components analyzed in starches were pentosans. The contents of total pentosans in all tested starches remained at a similar level of $0.60 \%$ dry weight. Although in the case of starch from soft wheat varieties slightly higher levels of this component than in the case of hard varieties were observed.

In the case of apparent amylose content the influence of hardness of wheat grain was also observed. For the starch isolated from wheat variety STH (soft), it was about $2 \%$ higher than in the starches from hard wheat varieties.

The resulting analysis shows that the total phosphorus content in starch from hard varieties ranges from $379.47 \mathrm{mg} / \mathrm{kg}$ for Tonacja variety through $430.91 \mathrm{mg} / \mathrm{kg}$ for Bombona wheat to $534.66 \mathrm{mg} / \mathrm{kg}$ for Sukces wheat, while for the soft variety STH it is equal to $477.63 \mathrm{mg} / \mathrm{kg}$. Based on the amount of phosphorus in starch one can conclude about the amount of lysophospholipids (its amount can be calculated from the amount of phosphorus in the batch). Starches which have a larger amount of phosphorus also contain a greater amount of lysophospholipids that may be associated with their surface or inside as an amylose-lipid complex or occur in free form, not bound in a complex with amylose.

The tested starches were also characterized in terms of total protein content of. Significantly higher amount of this component was observed in starch from STH soft wheat variety, average about $40 \%$, compared to starch from tested hard wheat varieties.

After using the selective solvent extraction of starch for each group, the percentage of surface and internal proteins in the fraction of total protein was calculated (Figure 1).

Based on the obtained results it was observed that starch from soft wheat variety (STH) contained a larger percent of the surface protein fraction in the fraction of total protein, than other wheat cultivars, characterized by higher grain hardness. In the case of starch from Bombona wheat variety, protein on the surface was not adsorbed. Thus, the influence of wheat hardness on starch chemical composition, can be seen. On the surface of starch granules isolated from hard wheat varieties an average of $40 \%$ to $70 \%$ less protein (Tonacja and Sukces respectively) was adsorbed compared to the surface of the starch granules of soft wheat varieties-STH. Results shown in Figure 1 indicate that most of the surface protein fraction in starch arepuroindolins.

The content of surface lipids in starches derived from typically soft STH wheat varieties $(0.36 \%$, Table 2$)$ was significantly higher, by about $35 \%$, than for starch obtained from wheat characterized by higher hardness. It can therefore be hypothesized that the higher content of surface proteins and lipids in starches from soft wheat varieties are closely correlated and interdependent. This may result from the existence of connections of proteins with lipids and their interactions on the surface of starch grains. A similar hypothesis was proposed by other authors [11] [30].

Starches were analyzed for the presence of surface proteins with a mass of approximately $15 \mathrm{kDa}$ and surface lipids, mostly glycolipids and phospholipids fractions, as determinants of quality of enzymatic glucose hydrolysates derived from these starches. Ongoing research aimed at explaining the role of specific polar lipids on the surface of starch granules in the binding of proteins to the surface of these grains. Selected starches derived from typically hard and typically soft wheat, clearly differed in protein and surface lipids content.

Presented electrophorogram (Figure 2) indicates the presence of significant amounts of protein with a molecular weight approximately $66 \mathrm{kDa}$ in all tested cultivars of wheat. Color of track no. 4 on the entire length of the plate indicates the presence of maximum number of surface proteins in starch from STH (soft) wheat variety. 


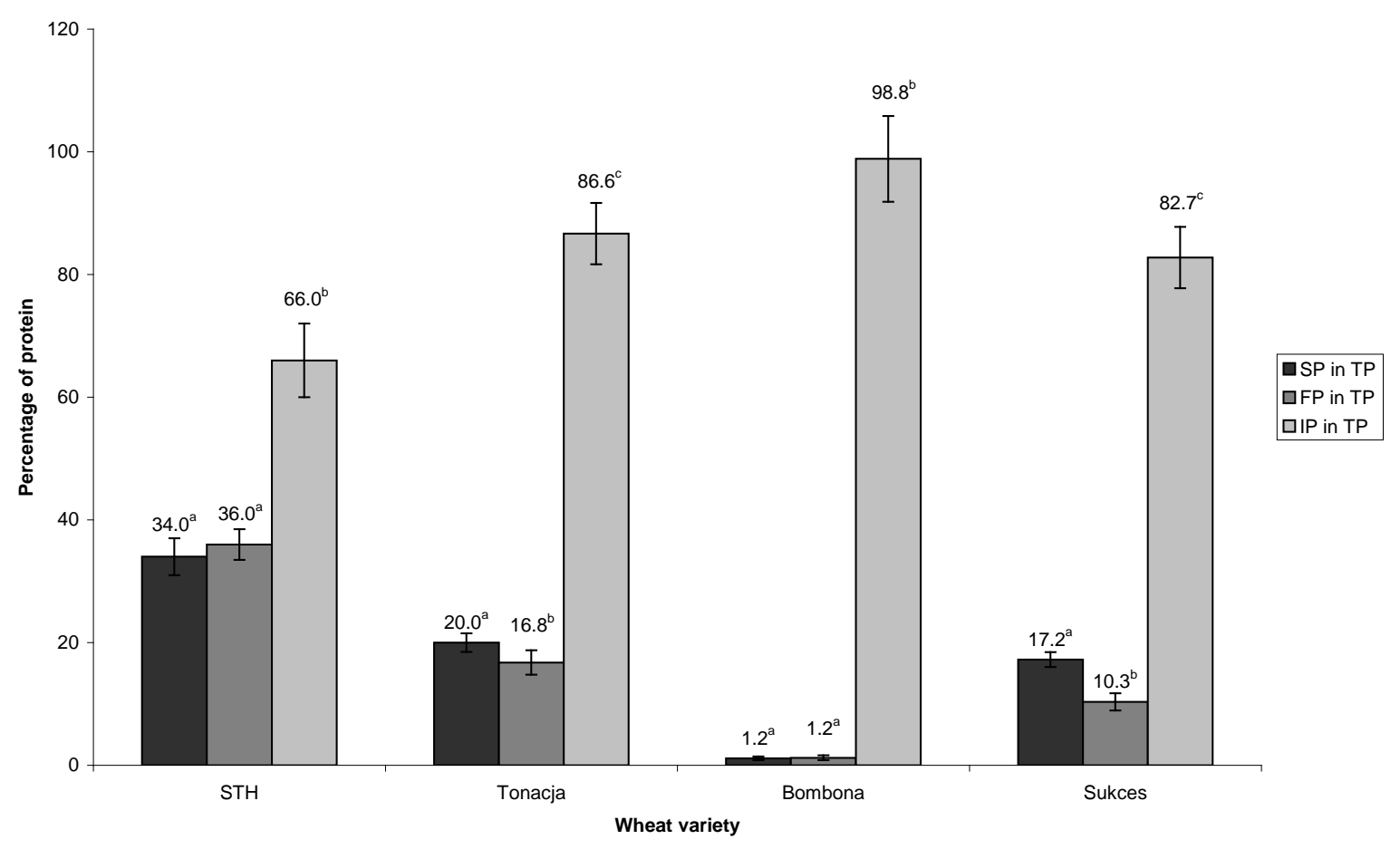

For legend

$\mathrm{SP}$ in TP

FP in TP

Surface proteins in total protein

IP in TP

The puroindolin fraction in total protein

Internal protein in total protein

Figure 1. Percentage of surface and internal proteins in the fraction of total protein in starch isolated from wheat grains of varying degrees of hardness. The values indicated by different indices literal characters, differ significantly $(\alpha=0.05)$.

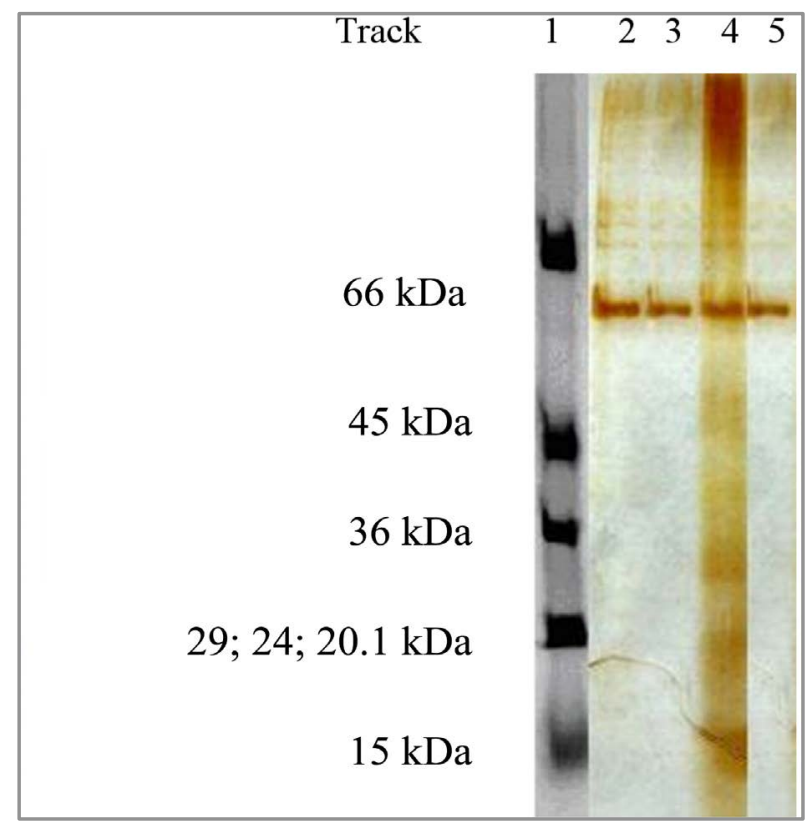

Figure 2. Electrophorogram of surface proteins of wheat starch. 1: Mass standard; 2: Tonacja, 3: Sukces, 4: STH, 5: Bombona. 
Moreover, the greatest intensity of color band indicating the presence of protein from a group of friabilins (puroindolins) with a molecular weight of $15 \mathrm{kDa}$ was observed for starch from this wheat variety. These results are related to the low value of hardness of STH wheat (Table 1).

For starch isolated from hard wheat varieties Tonacja, Sukces and Bombona only very small amounts of friabilin fraction were present on the presented electrophorogram.

This confirms that the amount of surface protein fraction is directly proportional to lipids present on the surface of starch grains. It was shown that surface lipids in starches from hard wheat varieties were present in much smaller quantities than on the surface of the starch grain.

Chromatographic analysis of surface lipids fractions in wheat starches.

Starch grain surface lipids of examined starches were isolated and analyzed using Thin Layer Chromatography (TLC). The representative thin-layer chromatograms of crude lipid extract provided in different solvent system are presented as Figure 3.

Staining chromatograms of crude extract of surface lipids showed the presence of neutral lipids, including sterols (Figure 3(a)) and large amounts of glycolipids (Figure 3(b) and Figure 3(c)). There were no qualitative differences in lipid composition between the hard (Bombona, Tonacja and Sukces) and soft (STH) varieties. Slight staining was observed in the chromatogram in the solvent system for phospholipids (data not shown) indicating a small quantity of these compounds in the investigated starches. The presence of significant amounts of staining compounds for glycolipids is indicated by the amount of spots in path 4 on Figure 3(b) and Figure 3(c) (soft TH variety), slightly less intense staining was observed in the case of all investigated hard varieties (Figure 3(b) and Figure 3(c), paths 1-3).

The crude extract was separated on a column of silica gel resulting in three fractions containing neutral lipids, glycolipids and phospholipids. The results of representative TLC are expressed as Figure 4.

The presence of neutral lipids has been demonstrated in all analyzed grains of starch (Figure 4(a)). It seems that the amount of such lipids is similar of both hard and soft varieties. Unexpected is weaker spot color for variety's Sukces, compared to other hard varieties. In contrast to the chromatograms of crude extracts of surface lipids, chromatographic separation of phospholipid fraction after SPE method shows the presence of small amounts of aminolipids (Figure 4(b)). Just as in the case of neutral lipids it seems that the amount of aminolipids is similar of both hard and soft varieties.

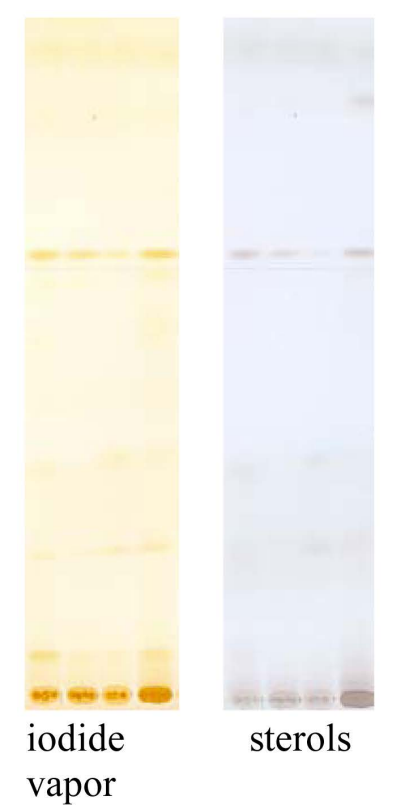

(a)

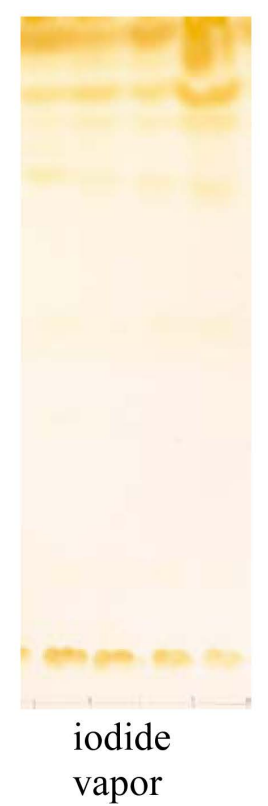

(b)

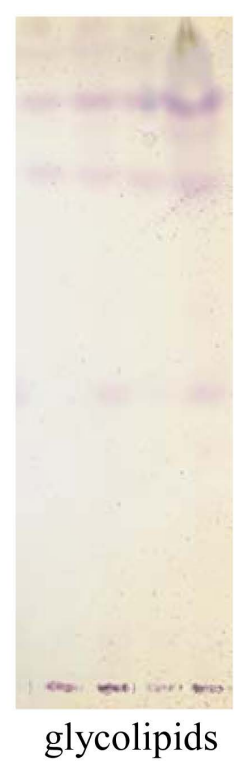

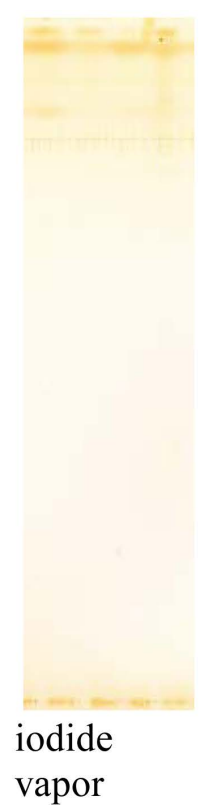

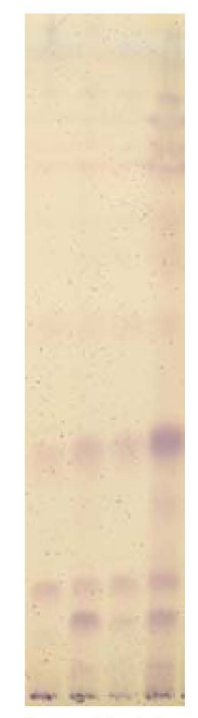

glycolipids

(c)

Figure 3. Chromatograms of crude extracts of surface lipids in the solvent system for neutral lipids (a), phospholipids (b) and glycolipids (c). On each plate the order of applying the lipid extracts was identical: Bombona, Tonacja, Sukces, and STH (from left to right). It was shown the type of staining below chromatograms. For more details see section Materials and Methods. 


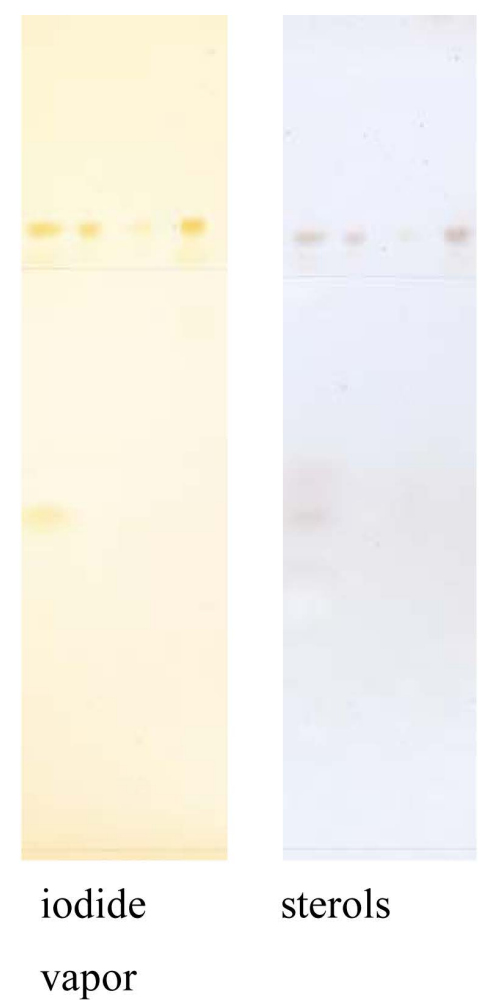

(a)

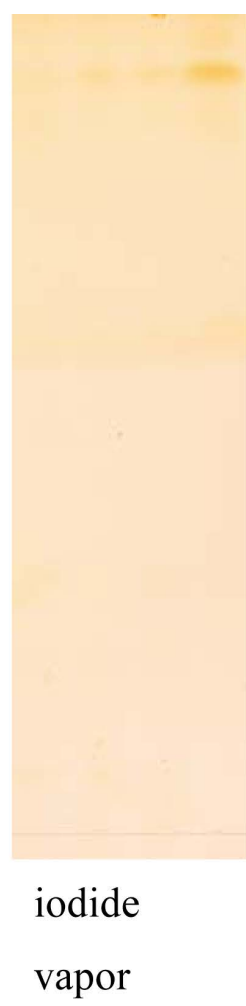

(b)

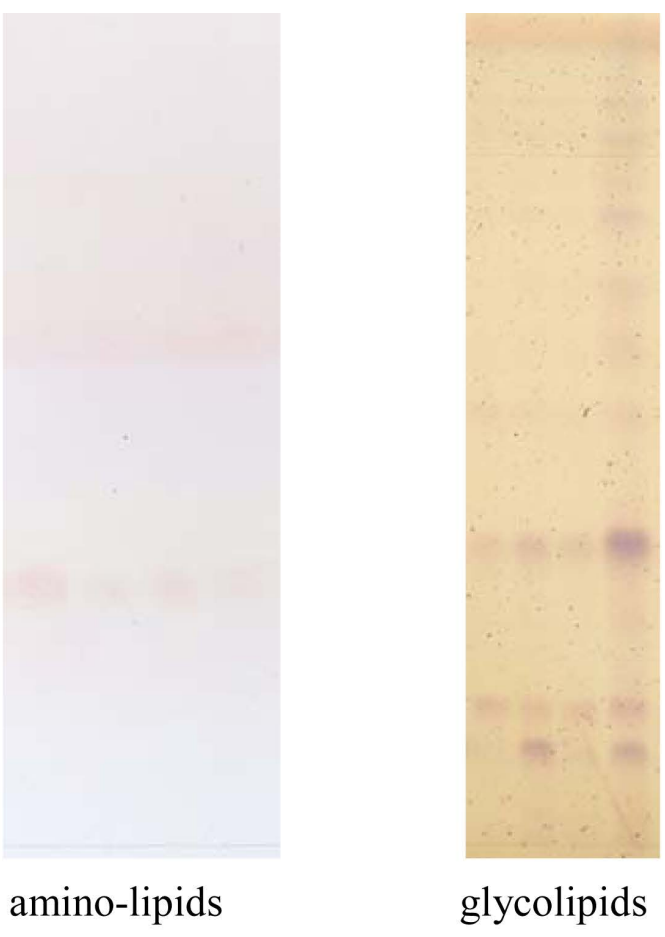

(c)

Figure 4. Chromatograms of separated fractions of surface lipids. (a) Neutral lipids in the system for neutral lipids; (b) Phospholipids in the system for phospholipids; and (c) Glycolipids in the system for glycolipids. On each plate the order of applying the lipid extracts was identical: Bombona, Tonacja, Sukces, and STH (from left to right). It was shown the type of staining below chromatograms. For more details see section Materials and Methods.

As in the case of chromatograms of crude extracts surface lipids, the largest amounts of lipids were observed in the fraction of glycolipids (Figure 4(c)). Analysis of the obtained chromatogram showed, that the variety of soft starch grains (STH) contains a greater amount of glycolipids, as well as their greater variation in quality compared to the varieties of hard (in the chromatogram observed more strongly stained spots).

Chromatographic analysis of surface lipids of tested starches indicates that the highest content of lipids (especially glycolipids) was found in the starch fraction of STH (soft) wheat variety, while the smallest amount of surface lipids was observed for starch of Sukces wheat variety (a typically hard wheat). In the starch from Sukces wheat variety (hard wheat) the amount of surface lipids was negligible and the proteins from the friabilins/puroindolins group were not observed on the surface. In other starches (from varieties of hard wheat) the presence of various lipid fractions was observed, but the stain bands on the chromatograms were clearly less intense than in the case of starch from STH wheat varieties (soft wheat variety).

Analysis of chromatograms and electrophorogram indicated the presence of significant amounts of surface proteins and lipids in starch from STH wheat variety (soft). In addition, there was no presence of proteins from friabilins/puroindolins group on the surface of grains of hard wheat starch (the other tested varieties), simultaneously the amount of surface lipids in these starches was negligible.

It is known [11], that the amount of both, surface lipids and proteins from friabilins/puroindolins group is very low in starches isolated from hard wheat varieties. It is believed that the presence of friabilins on the surface of the soft starch grains is associated with the presence of polar lipids, as indicated by theneed to use the appropriate solvents (SDS, propanol-salt) capable of breaking polar bonds between proteins and lipids to isolate friabilins [11].

Previous studies showed, that puroindolins Pin a and Pin b, belonging to the friabilin family, proteins with a molecular weight close to $15 \mathrm{kDa}$, bind lipids [12]. Dubreil, Compoint and Marion [12] and Wanjugi, Hogg, Martin and Giroux [31], pointed to the existence of differences in the ability to bind lipids between puroindolin 
isoforms (Pin a and Pin b). Pin a may closely bind both phospholipids and glycolipids on the surface of wheat starch. Pin b may interact with negatively charged phospholipids forming stable connections, but with glycolipids it can only form loose complexes. Ionic, hydrogen and hydrophobic bonds stabilizing puroindolin-polar lipids complexes and the presence of tryptophan domain is necessary for the interaction between the neutral polar lipids and PIN a to be possible [12].

Research conducted by Feiz et al., [30] confirm the relationship between gene expression (Pin) conditioning the presence of proteins from friabilin family and the presence of glyco- and phospholipids in starch grain. A number of evidence indicates that these genes directly affect the amount of polar lipids. There are many indications that the active surface proteins stabilize the polar lipids present there and prevent their decay, which occurs during grain ripening.

Results obtained in the course of the study also clearly indicate that the presence of polar lipids (glycolipids and phospholipids) on the surface of starch is related to their role in the binding of surface proteins fractions (friabilins) to the starch grains. Previous studies did not fully explain the role of surface lipids in the binding of proteins to the surface of starch, thus reasonable seems to conduct further analysis in this direction.

\section{Conclusions}

Analysis of chemical composition of starch grain surface can form the basis for the production technology of starch hydrolysates. The results of the analysis of starch composition (in terms of wheat grain hardness), determine the directions of its further processing. It was showed that starch properties, are among others, caused by the wheat grain characteristics, such as hardness. On the basis of obtained results concerning starch surface proteins and lipids, it can be determined whether the starch of the given wheat variety would be suitable for the preparation of hydrolysates with good physico-chemical properties.

The presence of lipids and proteins on the surface of starch grains affects their susceptibility to amylolytic enzymes, which is closely related to the quality of the hydrolysates. Initial quantitative and qualitative analysis of lipids and proteins on the surface of wheat starch grains, makes it possible to predict whether the type of starch obtained from wheat grain at a specified hardness will be useful for the preparation of glucose hydrolysates with good physicochemical properties.

Non-carbohydrate compounds present on the surface of starch grains (mainly lipids and proteins) have a negative impact on the properties of glucose hydrolysates. Research conducted by Nebesny, Rosicka-Kaczmarek and Tkaczyk [17] indicated that starches without surface compounds were better materials for the preparation of hydrolysates, as demonstrated by their improved properties, such as the sacharification degree, filtering time, color, hue and transparency.

Conducted research is therefore reasonable and should be continued because they can greatly facilitate the choice of suitable varieties of wheat, based on knowledge of their hardness, to isolate starch, from which hydrolysates with the best physicochemical properties may be obtained. These tests are inexpensive, not laborious and do not require big costs, and as results show they can serve as reliable information on the directions of the suitability of starch for further processing.

\section{Acknowledgements}

This study is financially support by the Ministry of Science and High Education Project in Poland No. N N312 314337.

\section{References}

[1] Konopka, I., Rotkiewicz, D. and Tańska, M. (2005) Wheat Endosperm Hardness. Part II. Relationships to Content and Composition of Flour Lipids. European Food Research and Technology, 220, 20-24. http://dx.doi.org/10.1007/s00217-004-1038-7

[2] Buleon, A., Colonna, P., Planchot, V. and Ball, S. (1998) Starch Granules: Structure and Biosynthesis. International Journal of Biological Macromolecules 23, 85-112. http://dx.doi.org/10.1016/S0141-8130(98)00040-3

[3] Ellis, R.P., Cochrane, M.P., Dale, M.F.B., Duffus, C.M., Lynn, A. and Morrison, I.M. (1998) Starch Production and Industrial Use. Journal of Science of Food and Agriculture, 77, 289-311. http://dx.doi.org/10.1002/(SICI)1097-0010(199807)77:3<289::AID-JSFA38>3.0.CO;2-D

[4] Finnie, S.M., Jeanuette, R., Morris, C.F. and Faubion, J.M. (2010) Variation in Polar Lipid Composition among Near 
Isogenic Wheat Lines Possessing Different Puroindoline Haplotypes. Journal of Cereal Science, 51, 66-72. http://dx.doi.org/10.1016/j.jcs.2009.09.006

[5] Finnie, S.M. and Faubion, J.M. (2009) Quantitative Characterization of Polar Lipids from Wheat Whole Meal, Flour and Starch. Cereal Chemistry, 86, 637-645. http://dx.doi.org/10.1094/CCHEM-86-6-0637

[6] Putaux, J.L., Nishiyama, Y., Mazean, K., Morin, M., Kardoso, M.B. and Chauzy, H. (2011) Helical Conformation in Crystalline Inclusion Complexes of V-Amylose: A Historical Perspective. Macromolecular Symposia, 303, 1-9. http://dx.doi.org/10.1002/masy.201150501

[7] Baldwin, P.M. (2001) Starch Granule-Associated Proteins and Polypeptides: A Review. Starch/Stärke, 53, 475-503. http://dx.doi.org/10.1002/1521-379X(200110)53:10<475::AID-STAR475>3.0.CO;2-E

[8] Giroux, M.J. and Morris, C.F. (1998) Wheat Grain Hardness Results from Highly Conserved Mutations in the Friabilin Components Puroindoline a and b. Proceedings of the National Academy of Sciences of the United States of America, 95, 6262-6266. http://dx.doi.org/10.1073/pnas.95.11.6262

[9] Douliez, J.P., Michon, T., Elmorjani, K. and Marion, D. (2000) Structure, Biological and Technological Functions of Lipid Transfer Proteins and Indolines, the Major Lipid Binding Proteins from Cereal Kernels. Journal of Cereal Science, 32, 1-20. http://dx.doi.org/10.1006/jcrs.2000.0315

[10] Bhave, M. and Morris, C.F. (2008) Molecular Genetics of Puroindolines and Related Genes: Allelic Diversity in Wheat and Other Grasses. Plant Molecular Biology, 66, 205-219. http://dx.doi.org/10.1007/s11103-007-9263-7

[11] Greenblatt, G.A., Bettge, A.D. and Morris, C.F. (1995) The Relationship among Endosperm Texture, Friabilin Occurrence, and Bound Polar Lipids on Wheat Starch. Cereal Chemistry, 72, 172-176.

[12] Dubreil, L., Compoint, J.P. and Marion, D. (1997) Interaction of Puroindolines with Wheat Flour Lipids Determines Their Foaming Properties. Journal of Agriculture and Food Chemistry, 45, 108-116. http://dx.doi.org/10.1021/jf960402j

[13] Oda, S. and Schofield, J.D. (1997) Characterization of Friabilin Polypeptides. Journal of Cereal Science, 26, 29-36. http://dx.doi.org/10.1006/jcrs.1996.0113

[14] Kooijman, M., Orsel, R., Hessing, M., Hamer, R.J. and Bekkes, A.C.A.P. (1997) Spectroscopic Characterization of the Lipid-Binding Properties of Wheat Puroindolines. Journal of Cereal Science, 26, 145-159. http://dx.doi.org/10.1006/jcrs.1997.0115

[15] Morrison, W.R., Law, C.N., Wylie, L.J. and Coventry, J. (1989) Seekings: The Effect of the Group 5-Chromosomes on the Free Polar Lipids and Bread Making Quality of Wheat. Journal of Cereal Science, 9, 41-51. http://dx.doi.org/10.1016/S0733-5210(89)80020-7

[16] Morrison, W.R. and Laignelet, B. (1983) An Improved Colorimetric Procedure for Determining Apparent and Total Amylose in Cereal and Other Starches. Journal of Cereal Science, 1, 9-20. http://dx.doi.org/10.1016/S0733-5210(83)80004-6

[17] Nebesny, E., Rosicka-Kaczmarek, J. and Tkaczyk, M. (2005) Influence of Selected Parameters of Starch Gelatinization and Hydrolysis on Stability of Amylose-Lipid Complexes. Starch/Stärke, 57, 325-331. http://dx.doi.org/10.1002/star.200400375

[18] Kerr, R.W. (1950) Chemistry and Industry of Starch. Academic Press Inc. Publishers, New York.

[19] (1996) PN-84/A-74706: Processed Starch. Methods of Test for Starch.

[20] AACC International Approved Methods of the American Association of Cereal Chemist, AACC Method 46-12.01, Crude Protein-Kjeldahl Method, Boric Acid Modification.

[21] Gazza, L., Corona, V., Boggini, G. and Pogna, N.E. (2001) Variation in Friabilin Composition as Determined by A-PAGE Fractionation and PCR Amplification, and Its Relationship to Grain Hardness in Bread Wheat. Journal of Cereal Science, 34, 243-250. http://dx.doi.org/10.1006/jcrs.2000.0416

[22] AACC International Approved Methods of the American Association of Cereal Chemist, AACC Method 40-75.01 Determination of Minerals by Inductively Coupled Plasma Spectroscopy.

[23] Hashimoto, S., Shogren, M.D. and Pomeranaz, Y. (1987) Cereal Pentosans: Their Estimation and Significance. I. Pentosans in Wheat and Milled Wheat Product. Cereal Chemistry, 64, 30-34.

[24] Higgins, J.A. (1987) Separation and Analysis of Membrane Lipid Components. In: Findlay, J.B.C. and Evans, W.H., Eds., Biological Membranes: A Practical Approach, IRL Press, Oxford, 103-137.

[25] Marinetti, G.V. (1964) Chromatographic Analysis of Polar Lipids on Silica Acid Impregnated Paper. In: James, A.T., Ed., New Biochemical Separations, Van Nostrand, London.

[26] Paściak, M., Holst, O., Mierzchała, M., Grzegorzewicz, A., Mordarska, H. and Gamian, A. (2004) Structural and Serological Characterization of the Major Glycolipid from Rothia mucilaginosa. Biochimica et Biophysica Acta, 1675, 54-61. http://dx.doi.org/10.1016/j.bbagen.2004.08.004 
[27] Lowry, R.R. (1968) Ferric Chloride Spray Detector for Cholesterol and Cholesterol Esters on Thin-Layer Chromatograms. Journal of Lipid Research, 9, 397.

[28] Laemmli, U.K. (1970) Cleavage of Structural Proteins during the Assembly of the Head of Bacteriophage T4. Nature, 227, 680-685. http://dx.doi.org/10.1038/227680a0

[29] Gromova, I. and Celis, J.E. (2004) Protein Detection in Gels by Silver Staining: A Procedure Compatible with Mass Spectrometry. In: Celis, J.E., Carter, N., Hunter, T., Shotton, D., Simons, K. and Small, J.V., Eds., Cell Biology, a Laboratory Handbook, Elsevier, San Diego, 219-223.

[30] Feiz, L., Wanjugi, H.W., Melnyk, C.W., Altosaar, I., Martin, J.M. and Giroux, M.J. (2009) Puroindolines Co-Localize to the Starch Granule Surface and Increase Seed Bound Polar Lipid Content. Journal of Cereal Science, 50, 91-98. http://dx.doi.org/10.1016/j.jcs.2009.03.004

[31] Wanjugi, H.W., Hogg, A.C., Martin, J.M. and Giroux, M.J. (2007) The Role of Puroindoline A and B Individually and in Combination on Grain Hardness and Starch Association. Crop Science, 47, 67-76. http://dx.doi.org/10.2135/cropsci2006.05.0310 
Scientific Research Publishing (SCIRP) is one of the largest Open Access journal publishers. It is currently publishing more than 200 open access, online, peer-reviewed journals covering a wide range of academic disciplines. SCIRP serves the worldwide academic communities and contributes to the progress and application of science with its publication.

Other selected journals from SCIRP are listed as below. Submit your manuscript to us via either submit@scirp.org or Online Submission Portal.
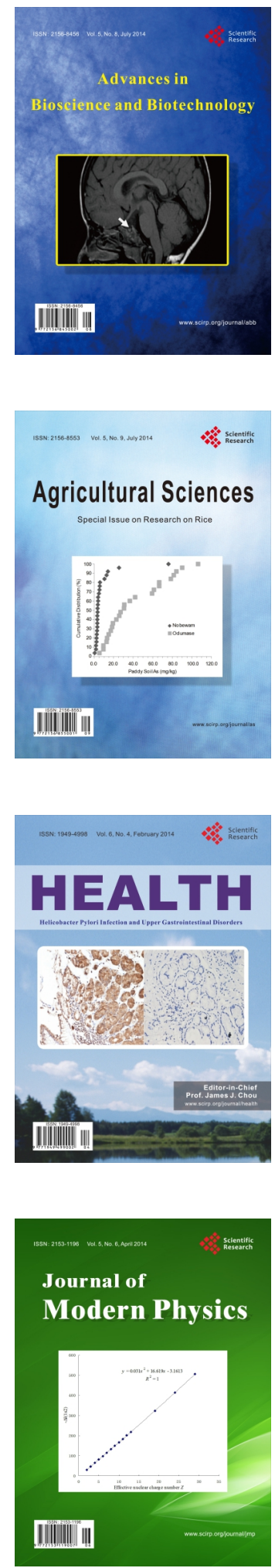
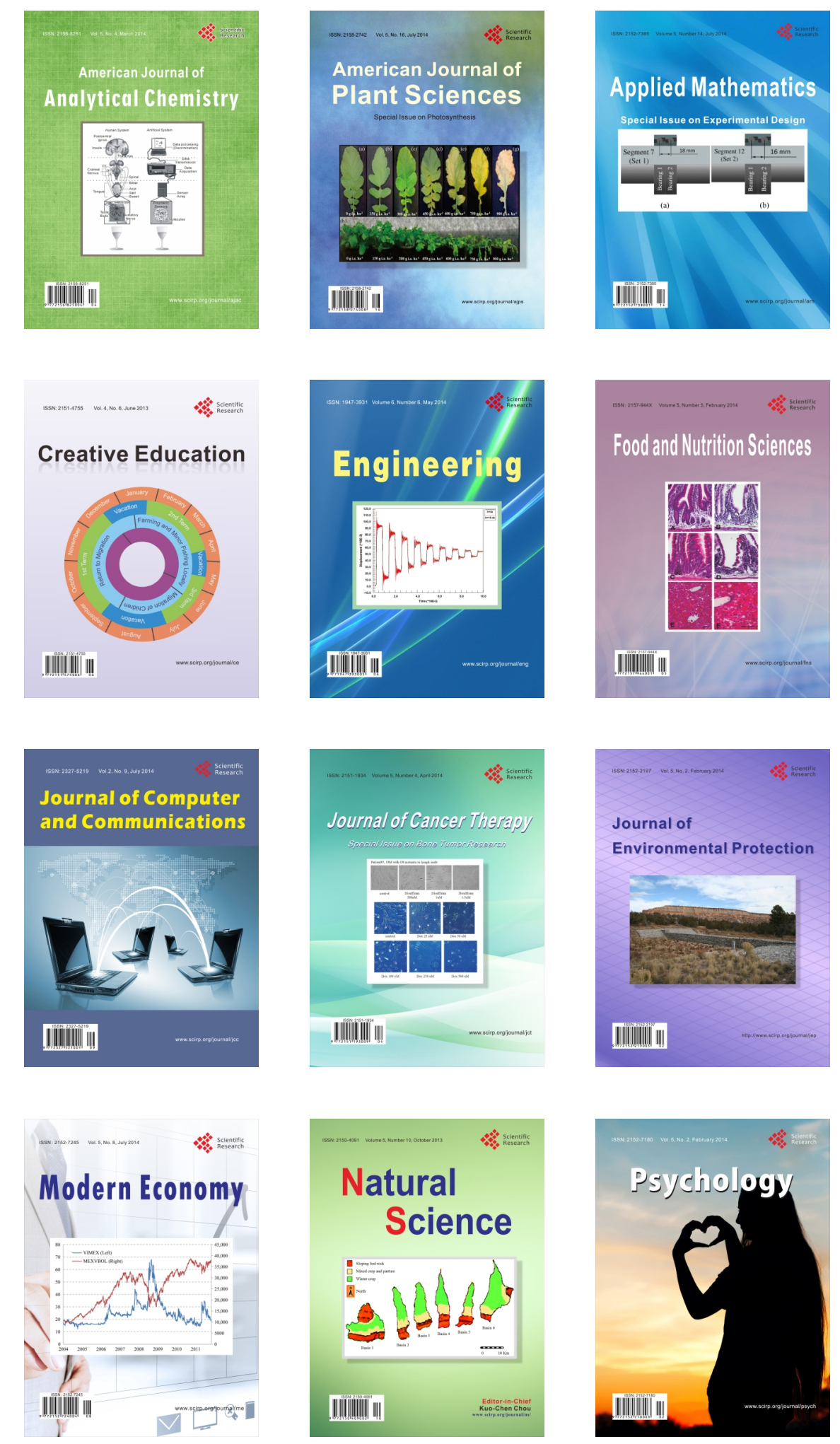